\title{
ASSESSING THE UK POLICIES FOR BROADBAND ADOPTION
}

\author{
Jyoti Choudrie \\ Business School \\ University of Hertfordshire \\ De Havilland Campus \\ College Lane \\ Hatfield \\ AL10 9AB \\ Tel:0044 1707284000 \\ Jyoti.choudrie@btopenworld.com \\ Anastasia Papazafeiropoulou \\ School of Information Systems, Computing and Mathematics \\ Brunel University \\ Uxbridge UB8 3PH \\ United Kingdom
}

Tel: 00441895274000

Fax: 00441895251686

Anastasia.papazafeiropoulou@brunel.ac.uk

ABSTRACT

Broadband technology has been introduced to the business community and the public as a rapid way of exploiting the Internet. The benefits of its use (fast reliable connections, and always on) have been widely realised and broadband diffusion is one of the items at the top of the agenda for technology related polices of governments worldwide. In this paper an examination of the impact of the UK government's polices upon broadband adoption is undertaken. Based on institutional theory a consideration of the manipulation of supply push and demand pull forces in the diffusion of broadband is offered. Using primary and secondary data sources, an analysis of the specific institutional actions related to IT diffusion as pursued by the UK government in the case of broadband is provided. Bringing the time dimension into consideration it is revealed that the UK government has shifted its attention from supply push-only strategies to more interventional ones where the demand pull forces are also mobilised. It is believed that this research will assist in the extraction of the "success factors" in government intervention that support the diffusion of technology with a view to render favourable results if applied to other national settings. 
Keywords: Broadband, UK, IT Diffusion and adoption, institutional theory, demand pull, supply push.

\section{INTRODUCTION}

Currently e-government is emphasising the capabilities that Information and Communication Technologies (ICTs) can offer. The potential currently being highlighted is the achievement of the transition from traditional, paper based transactions to efficient electronic egovernment services (Bakry, 2004). Apart from adopting electronic services for themselves through e-government initiatives, governments need to also design and implement policies that would facilitate the adoption of ICTs at national level. National interests in broadband clearly fall within this ICT policy trend. Technical broadband definitions vary widely (Firth and Kelly, 2001, Sawyer et al 2003), thus for the purpose of this research the technology neutral definition suggested by the Broadband Stakeholder Group (2001) is followed. Broadband is defined as 'always on access, at work, at home or on the move provided by range of fixed line, wireless and satellite technologies to progressively higher bandwidths capable of supporting genuinely new and innovative interactive content, applications and services and the delivery of enhanced public services' (BSG, 2001).

Broadband diffusion and capacity development have become central to the debates in many countries; principally surrounding the role of the government in developing broadband capacity; particularly focusing on the use of public money (e.g., BSG, 2004). Additionally within academia there are exploratory studies on broadband that have identified the policy issue as pertinent in understanding its diffusion amongst the public. Specifically the web of stakeholders that can be influenced as in the case of South Korea (Choudrie, et al, 2003a) or the mobile commerce opportunities arising from the use of broadband (Sawyer et al, 2003) are issues of interest.

Therefore, bearing these issues in mind, the research question guiding this paper is: What can be learnt about the role of government intervention for the future adoption of broadband technologies by examining some of the experiences of a country that is striving to have the most extensive and competitive broadband market in the G7 by 2005 (UK). In line with the research question, the aim of this paper is to extract the "success factors" in government intervention that support technology diffusion, based on the UK strategies in order to render favourable results if applied elsewhere. By offering the results of this research the contributions are considered to be two-fold. For academia this research offers a diverse perspective to examine the topic of the diffusion of broadband at the national level. For industry this research offers Internet Service Providers (ISPs) and regulatory agencies a perspective of areas where the strengths and weaknesses of the UK lie in and where they could offer support, thereby emphasising their stake in this important area.

The paper is structured as follows. First a brief overview of the UK broadband market is provided with an emphasis upon the particularities of the country. This section also describes the framework that assisted the analysis and findings to this research. In the third section the research methodology followed for this research is provided. The fourth section provides an analysis of the findings in line with the theoretical framework upon which this analysis is based. Section five provides a description of the diffusion strategies of UK government strategies in terms of the theoretical model used. Finally, some recommendations for government intervention in technology diffusion are provided. 


\section{THE PARTICULARITIES OF THE UK BROADBAND MARKET}

The UK government is targeting to have the most extensive and competitive broadband market in the G7 by 2005 (Arnott, 2003). It is predicted that broadband services offering higher connectivity and entirely new sorts of value added services will be a significant factor in determining national competitiveness over the coming years (BSG, 2004). By fulfilling this aim the government intends to achieve tremendous improvements in the economy via increased spending in the technology and telecommunications sectors. These efforts have been relatively successful. To date, there are over 6 million users of broadband within the UK with broadband penetration almost doubling in 2003 and 2004 to rise to about 10 per 100 inhabitants (Arnott, 2005). As illustrated in Table 1 below, the competition in technology in the UK is mainly between ADSL (Asynchronous Data Subscriber Line) and cable modem users with 1.6 million subscribed to ADSL and 1.3 to cable modem services at the end of August 2003 (Oftel, 2003).

Table 1: Broadband Subscribers (UK)

\begin{tabular}{|l|l|}
\hline & UK Broadband Subscribers (as at August 2003) \\
\hline ADSL & $1,600,000$ \\
\hline Cable Modem & $1,300,000$ \\
\hline
\end{tabular}

Source: Oftel (2003)

In terms of infrastructure development for broadband, the availability of ADSL services is expected to reach $99.6 \%$ of the population by the end of 2005 (Oftel, 2005a). The UK housing patterns are scattered, making infrastructure building difficult. With $80 \%$ of the UK population living in cities and towns and a housing population of over 10,000 people, but with a cover of some $7 \%$ of the land, thereby making connections between the ISPs exchanges and residential consumers difficult. Over $40 \%$ of the population live in London, the conurbations and the larger cities. That is, population density is greatest in London with 22 of the 25 most densely populated boroughs being in London. Kensington and Chelsea with 131 people per hectare (pph) is the most densely populated (Census, 2001a). Each of those major urban areas has a potentially wide influence. London is the second most densely populated region in Europe with the housing patterns being as follows. $81 \%$ are houses; 50\% are detached or semi-detached houses (ODPM, 2001). Recent figures suggest that broadband availability is highest in urban and suburban areas since the economies of density make it much more cost effective for its spread (BSG, 2004).

The UK is also exceptional as it is a diversely multi-cultural country in the world. Ethnic minority groups constitute approximately $8 \%$ (4.6 million people) of the total UK population (Census, 2001). These groups may not be fluent in English or even English literate. Particularly London had the largest proportion of minority ethnic groups. In Table 2 it can be seen that $2 \%$ of the English and Welsh population are Indian with Leicester having the largest number $(25.7 \%)$. Bangladeshis formed $0.5 \%$ of the population of England and Wales, with the highest proportion in the London borough of Tower Hamlets (33.4\%). Chinese people form more than $2 \%$ of the population in Westminster, Cambridge, City of London and Barnet. In England and Wales, $1.1 \%$ of people are Black Caribbean, $0.9 \%$ are Black African and a further $0.2 \%$ are from other black groups (Census, 2001b). Therefore, with such diverse populations constituting England Wales, local Councils, government departments, agencies and organisations have all been designated different roles in an attempt to socially 
include and provide e-government Services and Internet access to citizens (Teicher, et al, 2002).

Table 2: England and Wales' Ethnic Minority Population Distribution

\begin{tabular}{|l|c|}
\hline Ethnic Minorities Classifications & Percentages in England and Wales \\
\hline Indian & $2 \%$ \\
\hline Bangladeshi & $0.5 \%$ \\
\hline Chinese & $2 \%$ \\
\hline Black & $2.2 \%$ \\
\hline
\end{tabular}

Source: Census (2001)

According to Ofcom (the regulatory body of the UK telecommunications industry) (2003), there is vivid competition at the infrastructure level between the cable modem, DSL providers and numerous service providers competing to provide retail broadband services, thus reducing the prices. For the residential broadband services the prices in the UK are (when cable modems are excluded) similar to France and cheaper than all the other EU countries. France's prices are approximately $£ 22$ for monthly subscriptions while the same service in the UK is $£ 23$ (DSL is at a minimum bandwidth requirement of $257 \mathrm{kbps}$ downstream). Nevertheless, the UK government's vision for a competitive broadband market does not comply with the current image of the country in relation to competitive markets within the European Union and OECD. More specifically, in December 2004 broadband penetration per 100 people in the UK $(10.5 \%)$ was close to the OECD average, and held the number 14 position before other north European countries such as the Netherlands, Belgium and France (OECD, 2004b). The membership of the UK in the OECD provides the policy makers in the country with another incentive to diffuse broadband to the public as the OECD has called on governments/members to do more to encourage the development of broadband emphasising its importance for economic, social and cultural development and warning about the risk of missed opportunities from failing to do so. The OECD believes that without comprehensive action there is a danger that some countries could miss out on new market opportunities and growth through innovation and productivity increases (OECD, 2004a). Additionally, the EU regulatory framework requires member states (such as the UK) to review the main electronic communications markets (including broadband) in order to insure that regulation remains proportionate in the light of changing market conditions (Oftel, 2003).

Overall, broadband adoption in the UK is still currently relatively but there are high growth rates for residential penetration, with the UK occupying a "mid-table" position in the broadband connections worldwide. During 2004 the UK broadband penetration overtook Germany and is now slightly behind France but still lags behind South Korea, Japan, USA and Scandinavia (Ofcom, 2005a). As the analysis of this research demonstrates, the projections for the future are positive as both the government initiatives and the active engagement of the private sector in a competitive marketplace are indicators of a healthy market with potential future development. In the following section the theoretical framework of this study is presented. 


\section{SUPPLY PUSH AND DEMAND PULL IN TECHNOLOGY DIFFUSION}

In the case of Internet technologies such as broadband, although there is a tendency to move from localisation to globalisation, national governments still play a very important role in the design of strategies reflecting to a vision towards National Information Infrastructure (NII) (see (DTI, 1998; The White House, 1999; Ministry of Information and Communication (MIC), 2002)).

One approach for examining the role of the government in information technology diffusion was made by King et al. (1994) in their study that understood the role of the government and other institutions in IT innovation diffusion. They observed that, although the objectives of IT-related programmatic statements issued by various government agents are clear, the mechanisms used for the mobilisation of government leadership appear to be inefficient. They argued that difficulties in the application of IT diffusion polices are related to inefficient analysis of the role of institutions involved in the IT diffusion process. Similar to that, the motivation for using this framework for the analysis of this research was the criticism of the UK's programmatic statements by the OECD. More specifically, the goal of the UK government ("the UK having the most completive broadband market in G7 by 2005") has been criticised by OECD analysts as being concrete, too general and not clear enough in terms of information on the use of broadband and the technical and economic details of its employment (OECD, 2002).

King et al. (1994) used the institutional theory to examine the demand-pull and supply-push forces in government intervention for information technology diffusion. Supply push forces emerged from the production of the innovative product or process itself. Demand pull forces occurred as a result of the willingness of potential users to use the innovation. King et al (1994) also argued that governments can either be influential or regulatory. Influence is the persuasive power that an institution exerts over the practices, rules and belief systems of those under its sway. Regulation is the direct or indirect intervention in behaviour of those under the institution's influence. Combining the two modes of intervention with the two types of driving forces, they then defined six main institutional actions: knowledge building, knowledge deployment, subsidy, mobilisation, standard setting and innovation directive (see Figure 1).

\begin{tabular}{|l|l|l|}
\multicolumn{1}{c}{ SUPPLY PUSH } & \multicolumn{1}{c}{ DEMAND PULL } \\
\cline { 2 - 3 } INFLUENTIAL & Knowledge building & Knowledge deployment \\
Knowledge deployment & Subsidy & Subsidy \\
Innovation directive & Mobilization \\
\hline \multirow{2}{*}{ REGULATORY } & I & II \\
\cline { 2 - 3 } & III & IV \\
Knowledge deployment & Subsidy & Standards setting \\
& Standard setting & Innovation directive \\
Innovation directive & \\
\cline { 2 - 3 } &
\end{tabular}

Figure 1. Dimensions of Institutional Intervention (Source: King, et al., 1994) 
In this paper the time dimension was inserted into the framework in order to follow the changes that the government is achieving using institutional intervention that will obtain more promising results. More specifically, in the analysis undertaken in section 6 , an illustration of how the UK government is moving from a supply push drive and clearly influential one to a more regulatory and demand-pull oriented one is offered.

\section{RESEARCH METHODOLOGY}

As the time dimension was important for the analysis of this research a longitudinal case study was undertaken. A longitudinal study refers to data being collected for each variable for two or more distinct periods; the analysed subjects or cases are the same, or at least comparable, from one period to the next, and the analysis involves some comparison of data between or amongst periods (Menard, 1991). Therefore, the longitudinal aspect refers to the data collection that begun from June 2000 and is still in progress (that is, data is still emerging and being collected at the time that this paper was written). This is a strategy similar to other national diffusion studies (Lee and Choudrie, 2002, Lee et al, 2003). Table 3 presents the actions taken during the timeline of this study.

Table 3 Timeline of the study

\begin{tabular}{|c|c|c|c|}
\hline Year & $\begin{array}{l}\text { Institutional actions } \\
\text { examined }\end{array}$ & Use of primary data & Use of secondary data \\
\hline 2000 & $\begin{array}{l}\text { Knowledge building, } \\
\text { mobilisation }\end{array}$ & - & Articles, government reports, web sites \\
\hline 2001 & $\begin{array}{l}\text { Knowledge building, } \\
\text { mobilisation }\end{array}$ & - & Articles, government reports, web sites \\
\hline 2002 & $\begin{array}{l}\text { Knowledge deployment, } \\
\text { subsidy, standard setting, } \\
\text { innovation directive }\end{array}$ & $\begin{array}{l}10 \text { face-to-face } \\
\text { interviews }\end{array}$ & Articles, government reports, web sites \\
\hline 2003 & $\begin{array}{l}\text { Knowledge deployment, } \\
\text { subsidy, standard setting, } \\
\text { innovation directive }\end{array}$ & $\begin{array}{l}8 \text { face-to-face } \\
\text { interviews }\end{array}$ & Articles, government reports, web sites \\
\hline 2004 & $\begin{array}{l}\text { Knowledge deployment, } \\
\text { subsidy, standard setting, } \\
\text { innovation directive }\end{array}$ & $\begin{array}{l}8 \text { face-to-face }+2 \\
\text { telephone interviews }\end{array}$ & Articles, government reports, web sites \\
\hline 2005 & $\begin{array}{l}\text { Knowledge deployment, } \\
\text { subsidy, standard setting, } \\
\text { innovation directive }\end{array}$ & $\begin{array}{l}8 \text { face-to-face }+4 \\
\text { telephone interviews }\end{array}$ & Articles, government reports, web sites \\
\hline 2006 & $\begin{array}{l}\text { Knowledge building, } \\
\text { mobilisation, Knowledge } \\
\text { deployment, subsidy, } \\
\text { standard setting, } \\
\text { innovation directive }\end{array}$ & - & Articles, government reports, web sites \\
\hline
\end{tabular}

In order to obtain a holistic picture that would be rich in understanding, a qualitative approach that is based upon words rather than numbers was pursued (Miles and Huberman, 1994). For the data collection the process involved collecting and analysing both primary and secondary resources over a period of 7 years. The secondary resources were journal articles, press articles, government reports and web sites. The rational for the collection of the data was that in the first two years (2000 and 2001) where broadband was still in its infancy we 
collected information about the governments effort to create awareness about the technology thus examining knowledge building and mobilisation strategies. Later (from 2002 to 2005) we got a more detailed view of the rest of the strategies as they have been described in policy documents and explained by our interviewees. In early 2006 (the year when this paper was finilised) we included additional information coming from secondary resources related to all institutional actions. The primary data was collected using formal and informal interviews with relevant stakeholders. There were 10 face-to-face interviews that were undertaken in 2002, 8 in 2003 and 8 in 2004 and 2005. The interviews lasted for mainly an hour; however, some exceeded one hour and lasted for one and a half hours. There were also a number of informal (6) telephone interviews which took place in the last two years and were used in instances where distance or time was of an essence or as follow ups to face-to-face interviews and in such cases, the conversations lasted for between thirty and forty five minutes. The interviews were all hand written and in the instance of face-to-face, the interviews were also recorded using a Dictaphone.

The secondary data was pertinent in that it offered a starting point by allowing an identification of broadband patterns in the UK from 2000, the time that the vision was initially announced by the UK Prime Minister. This was ascertained by consulting and researching newspaper articles, archival documents and reports published upon the topics of broadband in the country.

Since then the researchers have been following the events that are assisting the government in achieving its aim in order to note any differentiating patterns. This particular strategy was useful in determining the questions that could be posed to the stakeholders who were questioned for this research. Additionally, although there was a rich and deep understanding obtained from the answers posed to the respondents, the data analysis revealed that some of the statistics required updating. For this purpose a revisit to the official statistical records was made and the changes were noted. For instance, when the research was begun, the numbers of broadband subscribers in the UK were less than a million subscribers; however, as this paper is being written the numbers of subscribers have increased to over six million. Therefore, it can be seen that by revisiting official statistical documents and undertaking the interviews triangulation of the findings occurred by verifying and validating the findings with previously or most recently published material.

For the analysis part, the results were categorised in terms of some themes that were considered pertinent for this research. That is, the findings were sectioned into the themes described in the sections of the theoretical framework. For instance, one of the themes included in the theoretical basis was that of knowledge building and mobilisation. Thus, an examination of the findings was undertaken in order to identify which of the data fitted in a particular theme and then placed it in that specific category, a strategy similar to some of the processes related to grounded theory (Strauss and Corbin, 1997). As an example, when obtaining the findings some of the explanations revealed that they could be classified into the mobilisation and/or knowledge building categories. However, we had to delve deeper to understand and discover that knowledge building involved the government finding ways of building the knowledge such that it could be understood by all; an aspect that mobilisation did not offer. Mobilisation involved a policing role. That is, the focus groups and other such parties had an impact upon and checked that the government was promoting a technology that could be obtained by all, regardless of class, creed or wealth. Therefore, for the researchers mobilisation involved searching for findings that illustrated how the interests of the public were being secured, whilst knowledge building elaborated how the information 
was being produced. From this it can be seen that the role of the themes was important in offering rigor to the research.

During the research process it was also noted that the research approach ran the risk of being biased by the optimistic views of the press and the persons involved in the process. To prevent such an instance, a solution to maintain a sound and balanced position was sought. For this, informal interviews were conducted with members of the government-regulating body Ofcom ( 2 members who made decisions directly related to the broadband area), members of the Broadband Stakeholder Group-a focus group that has been well recognised within the UK telecommunications industry for its efforts (3 executives); and members of the Broadband Task Force ( 2 decision makers). Opinions were also sought from leading academic experts (4, of which 2 research the broadband area and 2 others the telecommunications area) and other stakeholders, such as leading figures employed within the broadband sector of the incumbent monopolist organisation (BT) (4 managerial holding position holders)and other ISPs and then comparing their views to this research's findings. It was at this point that the process of investigator triangulation (the various individuals) also became pertinent again as it allowed a comparison of the primary and secondary data; thereby validating the data and published material and allowing theory triangulation. It can be noted that the participants from industry were selected based upon their influence over the decision making process, specifically over those of the government. The next section presents the research findings, by analysing the UK broadband diffusion strategies in terms of the institutional strategies described in the theoretical framework.

\section{ANALYSIS OF THE UK BROADBAND DIFFUSION STRATEGIES}

For the data collection and analysis part of the research the following process was followed. Initially the researchers asked the respondents open-ended random questions such as, 'How are organisations and households being made aware of broadband in your area?' Respondents replied by narrating to the interviewers the schemes that are being implemented within their local vicinities. For instance, in areas such as Devon and Plymouth, Small to Medium Sized Enterprises are receiving advice upon the use of broadband from agencies such as, UK Online. For householders schemes such as those established in the local libraries or establishing internet cafes are assisting in the diffusion of broadband. Therefore, the open ended questions assisted in obtaining the data for this research. Following this the analysis was undertaken where the researchers scrutinised the data that was received in the form of words and identified themes that were in the form of those stated below. That is, knowledge building, knowledge awareness. However, all the information was not obtained from the respondents; therefore, secondary data was then sought and assisted in filling the gaps. For instance, in the subsequent section titled 'Knowledge Building' details of the collaborative efforts between BT and the University of Eindhoven were obtained from the secondary data and then verified using primary data (the responses from the interviews). This step also demonstrates the use of triangulation.

\section{- Knowledge building}

The UK government is seeking to extend the broadband infrastructure development by examining other types of connections apart from DSL and cable modems (Oftel, 2003). This is being undertaken with organisations such as, British Telecom (BT) and the cooperation of other suppliers in trials such as the Remote Broadband Inclusion Trial. A world first in the broadband area-an ultra high-speed switching system field trial for optical fibre networks was also achieved through a collaborative effort between BT, Siemens and the Technical 
University of Eindhoven (Siemens, 2003). To prevent rural areas from being excluded, initiatives are also being pursued with the assistance of European funding. One such example is the Western Isles Connected Communities project that has been awarded European funding in order to build an innovative wireless broadband network throughout the Western Isles. The funding was announced by the Scottish Executive as one of a number of projects to receive funding from the Highlands \& Islands Special Transitional Program (Connected Communities, 2004).

However, wireless technology (Wi-Fi or Wireless Fidelity) in the UK as in other parts of the world, is not only being implemented to and restricted to connecting only rural areas, but is being applied to link large vicinities. Wi-Fi allows for Internet access within computer networks without the aid of wires and can connect Portable Computers'(PCs), Notebooks and Personal Digital Assistants (PDAs) to enable them to share internet connections, printers and documents. Wi-Fi can function at a distance of about 300 feet. Its ability to group computers without wires means its common place in public places, such as hotels, airports, coffee shops and offices (Anonymous a, 2006).

Within the UK Wi-Fi is being offered by forming working partnerships, such as that by Cloud and BT and BT and Intel (Richardson a, 2006). Currently, Cloud's Wi-Fi kit is installed in places such as pubs, coffee shops and train stations, but this is the first time it has attempted to bring wireless broadband to urban areas on a large scale (Richardson b, 2006). BT is pressing ahead with plans to wire up six cities with wireless broadband access. It's already started in Cardiff, where BT Openzone hotspots have been installed in locations in the city centre, while in London's Westminster, BT has decided to expand an existing wireless network. Other cities on BT's "to do" list are Birmingham, Edinburgh, Leeds and Liverpool, forming the first phase of plans to wire up a dozen UK cities. The country's largest Wi-Fi network has been launched in London. Thames Online will provide about $12 \mathrm{~km}$ of seamless coverage - from Westminster to Greenwich - along the river. Recently, the government has also recognized the potential of Wi-Fi and intends to promote it even further by recommending that there are boosts to the signals used in Wi-Fi networks. This way greater savings will be incurred due to the numbers of transmitters for wired technology being lesser and larger areas obtaining broadband access (Anonymous b, 2006).

\section{- Knowledge deployment}

Recently the UK government has recognised the importance of the deployment of technology and has begun to provide funding for education on ICTs. This has been implemented by government departments such as, the Department of Further Education and Skills (DfES) which is spending GBP 79 million from the Standards Fund to provide schools in England with broadband access to the Internet. The fund is allocated to a number of regional broadband consortia. Additionally, the government invested $£ 3$ million in the education and training of private organisations in programmes known as e-skills UK. This has become one of the first of 23 sector skills councils being created to give employers a direct input to government training policy and the development of courses in schools, colleges and universities (Goodwin, 2003).

The government is also promoting use of computers amongst the older generations by having buses travelling around the country and introducing this group of the society to the benefits of this technology (Cushing, 2002). This focus upon the older generation, unemployed individuals such as, housewives and those out of jobs has also led to the government to focus 
upon trusted and easily located places; specifically the libraries where free access is provided. This has led to the creation of the People's Network whereby the vision of the government is the driving force, but the funding is being provided by the New Opportunities Fund of the National Lottery (MLA, 2004). Additionally the government has opened approximately 600 training centres that are located within easy access of the citizens. Therefore, diverse local community centres, shopping centres, pubs, football clubs and funfairs are providing training and knowledge about IT (Lynch, 2001).

\section{- Subsidy}

The UK government favours a market-led approach in conjunction with a drive towards aggregating the public sector demand for broadband (Wearden, 2002). Nevertheless, various subsidies are injected indirectly by public/private sector initiatives such as the one developed by Coventry University. This initiative will offer funds of more than GBP 7 million to small and medium size businesses (SMEs) in Coventry and Warwickshire. The funds are being used to make the SMEs become more competitive by exploiting broadband networking. Similarly, the Powys County Council together with the Welsh Development Agency (WDA) established a project that encourages the public and private sectors to form partnerships. By doing so, there is an upgrade to the broadband network that supports the provision of the technology in rural Wales. Scotland also has an initiative 'Broadband for Scotland' whereby there is a drive to encourage broadband amongst the consumers and businesses alike by pursuing campaigns fronted by famous Scottish media personalities and publicising the benefits of broadband using campaigns run on the radio, and newspapers. Additional information and general assistance is also provided to members of the public using web sites and hotlines (Scottish Executive, 2003).

\section{- Mobilisation}

Communities, focus groups and the media have been working hard to describe the potential of this technology. In the UK, for example, the focus group Broadband Stakeholder Group in its first annual report recommended a strategy for accelerating the broadband penetration which included 15 strategic recommendations in three areas: accelerating market driven deployment and take-up, enabling public sector driven deployment and use, and ensuring appropriate regulation (BSG, 2002). While 14 out of 15 recommendations were accepted by the government, one recommendation on fiscal policy for tax incentives to boost the broadband infrastructure was refused (Adshead, 2001). This caused a campaign called 'Broadband Britain?' to occur from the industry to urge the government to act in order to meet its pledge for the most competitive broadband market to be formed by 2005 (Arnott, 2003).

\section{- Innovation directives}

The UK government similar to most current governments around the globe is making substantial investments to the e-government initiatives. In 2000 the Prime Minister pledged $£ 1$ billion to e-government initiatives and as a result an electronic service has been established for organisations interested in investing in the UK and to provide information and services, such as training into how to conduct e-business in other countries, to learn of the new cultures and the way that they conduct business, and financial assistance can also be 
provided by qualifying for specific awards. Such measures should allow British organisations determined or already established in foreign shores to make a mark in the international markets (DTI, 2002). Citizens are also being catered for. For instance, parents can obtain online information about schools within the country and pension bearing citizens can find out about their pensions and receive payments electronically (Lynch, 2001). Additionally, the National Health Service (NHS) is committed to provide all hospitals and the majority of general practitioners with broadband connections. The government is also committed to provide all public libraries in the UK with broadband connections. In terms of the success of the e-government projects, the UK was viewed to be eighth amongst twenty two countries for its e-government initiatives (Lynch, 2001).

\section{- $\quad$ Standard setting}

The UK government has lately realised the importance of standards setting with reference to buildings and is now in the legislator planning stages in the building industry with the view to offer broadband infrastructure to households such cable and wireless connections (Wearden, 2003). Additionally, Ofcom the regulatory body in the UK has been working towards redefining broadband as there are Internet Service Providers (ISPs) attempting to confuse consumers with the prices imposed upon the consumers (Richardson, 2003). In order to ensure that the members of the public are obtaining broadband at a fair price the regulatory body Ofcom has recently announced that connection and shared access prices should fall by about $70 \%$. This act has been called for despite the incumbent monopolist British Telecom (BT) also reducing the subscription fees prices charged to the consumers by almost $70 \%$, earlier on in 2004 (Richardson, 2004). Although Ofcom has a relaxed regulatory approach concerning BT's availability of Local Loop Unbundling (LLU) to the market, it also seems to be ready to take a more formal regulatory approach if necessary (Ofcom, 2005b).

In the UK, the government established a clear goal in 2000 by stating that broadband technology will allow the country to become an e-commerce leader within the G7. The strategy of the government is the provision of leadership on broadband by setting the goal as well as creating a strategic partnership with key players in the private and public sectors, and continues to drive forward competition in the supply of infrastructure and services.

Thus, according to the analysis of this research the policies pursued by the government initially were mostly influential with an emphasis on the supply push (represented by I in Figure 2), leaving the competition to lead the market. After undertaking a long-term approach to the subject it can be seen that currently, as the government's goal seems to remain unapproachable with broadband take-up being relatively low the government is looking at developing educational programs that enforce the demand pull while considering also the regulation of the vendors market. The results of these efforts are encouraging as there are an increased number of subscribers (explained earlier in the paper) and positive projections for the future. Figure 2 presents the UK government's strategy development, whereby taking the time dimension into consideration we can see that there is a move (represented by the arrow) from influential, supply push strategies to more aggressive polices towards regulation development and demand pull. 


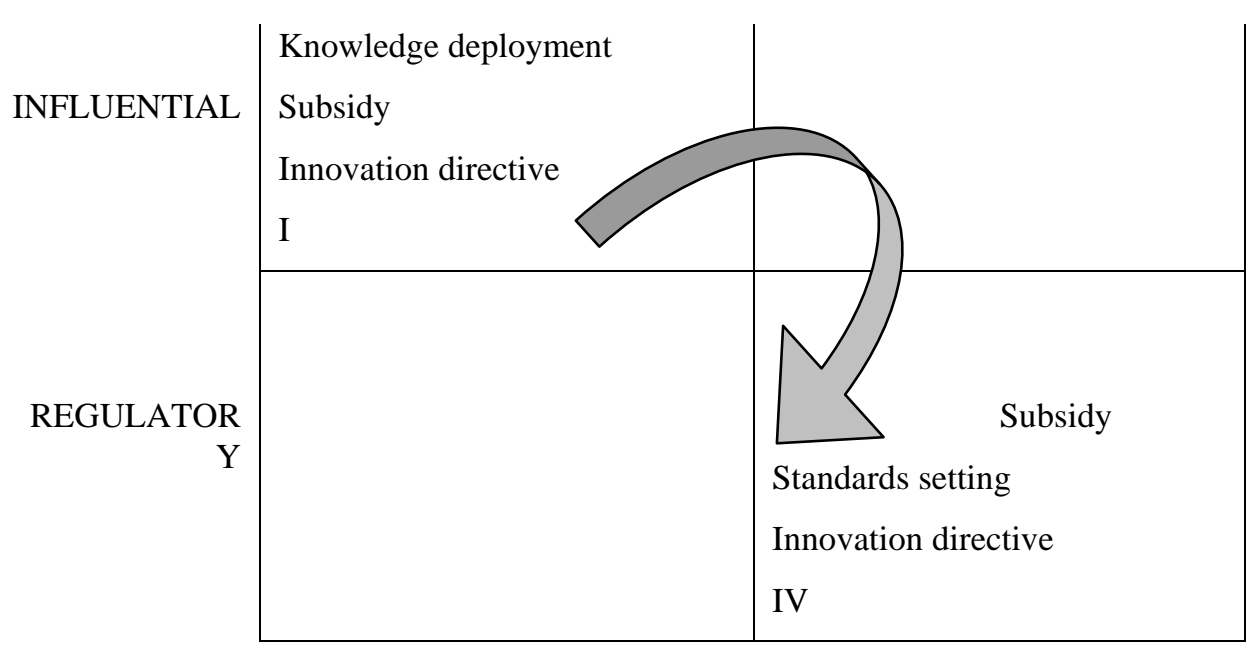

Figure 2: The progression of the UK broadband strategy

The results of this analysis demonstrated that the principles of UK broadband diffusion strategy that pursues a pro-market policy is far from the traditional interventionist government such as the one followed in for instance, South Korea-a country that is by far the leader in broadband adoption (Choudrie et. al., 2003). Given the tendency in the UK, BT's action to aggressively promote broadband in 2002 cannot be attributed directly to the government influence. At the same time, however, it cannot be denied that the government's push for the ambitious goal of being a broadband leader in Europe did not affect the incumbent operator's action. Additionally, a variety of measures implemented by the government contributed to changing the broadband environment, while according to this research's analysis there is a tendency of the UK government to begin being more interventionist in its approach to broadband diffusion.

The findings of this research are novel in the sense that they offer a long-term in-sight to a government's move from a strictly market-led approach to a more interventional strategy. This shift could have been influenced by the unique social and cultural characteristics of the UK, where as explained in section 2 include the geography and cultural diversity of the British population. More specifically, the scattered housing patterns made the overall availability of the broadband technology difficult, while the lack of Internet literacy in specific parts of the population pushed down the demand for broadband technologies. Whether the government sensed early enough these indicators of low broadband adoption is a subject of further debate at political level given the fact that UK broadband adoption is rather low in comparison to other EU and OECD member countries. The type of research undertaken in this study could be instrumental is helping policy makers to realise the effectiveness and flexibility of their strategies and help them take timely decisions concerning future directions of policies of broadband in particular and technology diffusion in general.

\section{IMPLICATIONS OF THIS RESEARCH AND FUTURE DIRECTIONS}

It is believed that this research has implications not only for the role of government in broadband diffusion but IT diffusion in general. An important issue that should concern policy makers when it comes to their decision to intervene in the diffusion of new technologies is the extent that national leadership should be mobilized to stimulate IT innovation and use. Additionally, it is interesting to note that although the clarity of the objectives of the IT relevant programming statements is provided, the appropriate policies for 
government action are not clear. In the case of the UK government, its intention to have a competitive broadband market was not supported by its actions towards broadband diffusion. The low numbers of broadband adoption were nevertheless an incentive for the government to mobilize more actions and have more institutions involved towards the achievement of the programming statements.

It is apparent that the institutional intervention cannot only be applied exclusively by the national government. For example, knowledge production never happens within the government but public authorities at national level have a role in supporting research and development for the production and application of new ideas. A wider participation of a number of institutions is essential for the avoidance of oligopoly and elitist actions. These organizations are universities, hardware/software vendors as well as professional and trade associations. The efforts of these organizations can be harmonized under the guidance of an entity that has the vision, which also is not necessarily the government. Specifically, the role of telecommunication providers is considered as very powerful, but their actions need to be regulated by an intermediary organization that will help in promoting competition. Although each national setting is different in terms of culture, geography and social structure we believe that our analysis can be useful for policy makers seeking to promote broadband, which in turn can assist in obtaining e-government services in the future.

As in the instance of every novel technology, its successful application depends upon the context and the special circumstances where this is applied. In other words, in the case of broadband, this research recognizes that the application of the framework is not appropriate for every single case and without having a pre-innovation bias towards broadband; it is believed that this analysis is useful to policy makers and technology providers that seek to promote new technologies. Hence, future directions include applying the framework to other novel technologies entering the market.

Additionally researchers in the field of IT diffusion can benefit by realizing the role of the government and other powerful organizations in the production and diffusion of new technologies.

Therefore, from these conclusions it can be deduced that when examining the diffusion of a technology that will affect the economy as a whole, a stakeholder whose role is crucial is the government. However, for government to promote, support and implement the intended policies the role of other stakeholders is pertinent; for instance, in this research the positions of academic institutions and ISPs were considered important. Subsequently, for this purpose, partnerships and co-operation from various sectors of the economy with the government are vital.

Future directions for this research include examining the attributes of broadband as an innovation (Rogers, 2003) that has the potential to impact a citizen's use of Information technology, the Internet in particular. Additionally the examination of the digital divide between countries and within countries (Papazafeiropoulou and Pouloudi, 2003) in terms of broadband adoption as well as cultural issues (see for example (Chai, Pavlou 2004)) related to its adoption in will be areas for future research. 


\section{REFERENCES}

Adshead, A. (2001). Broadband block to Britain's business. Available at: http://www.computerweekly.co.uk/articles.

Anonymous (2006a). Definitions of What is Wi-Fi on the Web. Available at: http://www.hardwarefusion.net/index.php

Anonymous (2006b). Wi-fi boost plan for rural areas. Available at: http://www.bbc.co.uk/1/hi/technology/5230460.stn.

Arnott, S. (2005). UK climbs to 14th in the world broadband league. Available at: http://www.computing.co.uk/news/1163399

Arnott, S. (2003). 2005 deadline for broadband Britain. Available at: http://www.computing.co.uk/News/1148541

Bakry (2004). 'Development of E-government: A STOPE view.' International Journal of Network Management. 4, pp. 339-350.

Broadband Stakeholder Group (BSG), (2001). Report and Strategic Recommendations. Available at: http://www.broadbanduk.org/reports/report03.htm

BSG (2004). Third Annual Report and Strategic Recommendations. Available at: http://www.computing.co.uk/News/1148541

Census (2001a). “Census 2001 - Population of England and Wales grows 2.5 per cent." Available at:

http://www.statistics.gov.uk/census2001/profiles/commentaries/people.asp

Census (2001b). “Census 2001 - Ethnicity and religion in England and Wales.”Available at: http://www.statistics.gov.uk/census2001/profiles/commentaries/ethnicity.asp

Chai, L., Pavlou, P.A., (2004), 'From "ancient" to "modern": a cross-cultural investigation of electronic commerce adoption in Greece and the United States', Journal of Enterprise Information Management 17(6): 416-423

Choudrie, J. Papazafeiropoulou, A. and Lee, H. J. (2003). A Web of Stakeholders and Strategies: A Case of Broadband Diffusion in South Korea. Journal of Information Technology, 18, (4), pp. 281-91

Choudrie, J. and Lee, H.J. (2004). Broadband Development in South Korea: Institutional and Cultural Factors, European Journal of Information System, pp. 103-114.

Connected Communities (2004). European Funding Announced for Connected Communities Project.www.connectedcommunities. co.uk

Cuddy, I. (2003). New moves for European eGovernment. Viewed at http://www.egovmonitor.com/newsletter/yzdqasd86/talrln02.html 
Cushing, K. (2002). IT gets on the bus to reach OAPs. Available at: www.computerweekly.com. April 18.

Dempsey, J.X. (2001). How E-Government Interacts With Its Citizens. Transition Newsletter. Viewed on $22^{\text {nd }}$ October 2003 at: www.worldbank.org

Department of Trade and Industry (DTI) (1998). 'Net Benefit: The Electronic Commerce Agenda for the UK, forwarded by Barbara Roche', DTI, London.

Firth, L. and Kelly, T. (2001). Broadband briefing paper, ITU, Geneva. Available at www.itu.int/broadband

Goodwin, B. (2003). E-Skills to tempt 40,000 into IT. Available at: www.cw360.com. 8 April

King, J., Gurbaxani, V., Kraemer, K., McFarlan, F., Raman, F. and Yap, F. W. (1994). 'Institutional factors in information technology innovation', Information Systems research, 5(2): 139-169.

Lee, H. J. and Choudrie, J. (2002). Broadband Deployment in South Korea. Brunel-DTI, International Technology Service

Lee, H., O'Keefe, R.M.. and Yun, K. (2003). "The Growth of Broadband and Electronic Commerce in South Korea: Contributing Factors". The Information Society 19(1): 8193.

Lynch, I. (2001). UK only eighth in e-government stakes. http://www.pcmag.co.uk/News/1120293. April 9.

Menard, S. (1991). Longitudinal Research, Sage, Newbury Park.

Miles, M.B., Huberman, A.M. (1994) Qualitative Data Analysis: An expanded sourcebook (2nd edn.), Sage:London \& Thousand Oaks, California

Ministry of Information and Communication (MIC) (2002). 'IT Korea 2002', Ministry of Information and Communication (MIC), Seoul, South Korea.

MLA (2004). The People's Network. Available at: http://www.peoplesnetwork.gov.uk

Northrup, T.A. and Thorson, S.J. (2003). The Web of Governance and Democratic Accountability. Proceedings of the $36^{\text {th }}$ Hawaii International Conference on System Sciences (HICSS).

Office of the Deputy Prime Minister (ODPM) (2001). National Statistics Online-Census 2001. Viewed on November 2003 at: http://www.statistics.gov.uk/census2001/ 
OECD (2002). 'Broadband Infrastructure deployment: The role of government assistance', Organisation of Economic Co-operation and Development (OECD), Paris.

OECD (1997). 'Government venture-capital for technology based firms', OECD (Organisation for Economic Co-operation and Development), Paris.

OECD (2004a). Benchmarking Broadband Prices in the OECD. Available at: http://www.oecd.org/dataoecd/58/17/32143101.pdf

OECD (2004b). OECD broadband update - December 2004. Available at: http://www.oecd.org/document/60/0,2340,en_2649_201185_2496764_1_1_1_1,00.ht $\mathrm{ml}$

Ofcom (2004). The Ofcom Internet and Broadband Update - April 2004. Available at: http://www.ofcom.org.uk/research/consumer_audience_research/telecoms/int_bband_ updt/may2004/

Oftel (2003). 'Oftel's Internet and Broadband Brief' Ofcom (Office of communications) available at:

http://www.ofcom.org.uk/legacy_regulators/oftel/oftel_internet_broadband_brief

Ofcom (2005a). 'The communications Market 2005' available at: http://www.ofcom.org.uk/

Ofcom (2005b). 'Broadband regulation' available at: http://www.ofcom.org.uk/

Papazafeiropoulou, A. \& Pouloudi A. (2003). Applying the normative aspect of stakeholder analysis to electronic commerce policy making: Stakeholder considerations for the elimination of the digital divide. Proceedings of the Thirtieth-sixth Hawaii International Conference on Systems Sciences (HICSS-36), IEEE Computer. January 6-9, Big Island, Hawaii.

Richardson, T. (2003). 'Oftel redefines broadband', http://www.theregister.co.uk (viewed October 15, 2003).

Richardson, T. (2004). 'Ofcom reveals prices for LLU', http://www.theregister.co.uk (viewed on September 2, 2004).

Richardson, T. (2006a). BT backs city-wide Wi-Fi. Available at: http://www.theregister.co.uk/2006/05/17/bt_wifi/. Viewed on August 1, 2006.

Richardson, T. 2 (2006b). The Cloud targets UK with city centre Wi-Fi hotspots. Available at: http://www.theregister.co.uk/2006/05/17/bt_wifi/. Viewed on August 1, 2006.

Rogers, E. (2003). The Diffusion of Innovations. Free Press, New York. Fifth Edition. 
Sawyer, S., Allen, J.P. and Lee, H.J. (2003). Broadband Mobile Opportunities: A SocioTechnical Perspective. Journal of Information Technology. June, 18, pp. 121-36.

Scottish Executive (2003). 'Broadband for Scotland' campaign. Available at: http://www.scotland.gov.uk/pages/news/2003/11/SEEL184.aspx

Siemens (2003). Siemens, BT and the Technical University of Eindhoven achieve significant breakthrough for future UK broadband networks. 'www.siemens.co.uk

Strauss, A. and Corbin, J. (1997), Grounded Theory in Practice, California, SAGE Publications.

Teicher, J., Hughes, O., and Dow, N., (2002). "E-Government: a new route to public sector quality". Managing Service Quality, Volume 12, Number 6, pp 384 - 393

The White House (1999). 'Facilitating the growth of electronic commerce', The White House, Washington.

Wearden, G. (2002). E-COMMERCE MINISTER: NO RURAL BROADBAND SUBSIDIES. Available at: http://news.zdnet.co.uk/story/0,t269-s2112337,00.html. June 24. 